Public Archaeology, Vol. 15 Nos. 2-3, May-August 2016.

\title{
Beverley Butler
}

\section{University College London, UK}

In this paper I present critical insights into the efficacies of heritage. I take the phenomenon of the Jerusalem Syndrome (JS) as my point of departure and recast it as Heritage Syndrome (HS). I do this to better understand how such efficacies are experienced and materialized in ritual possessional acts. As a framework, the JS reveals the power and potency that reside in experiences of collapse. Such disembedding events activate subsequent ritual dramas (whether malign/benign or successful/failed) of world-making, redemption, repair, and renewal. Heritage quests as ritual 'sacred dramas' and 'practical magics' are I argue, similarly experienced in the collapse of known categories: imagined/real, extraordinary/mundane, possessing/being possessed, and crucially what heritage is versus what heritage does. Writ large, heritage efficacies are bound-up in the breakdown and blurring of boundaries - and thus the non-distinction - between heritage in the conventional sense and other dynamics such as magic, prophecy, and well-being/ill-being. These reveal alternative pathways, potentialities, and patterns of behaviour that demonstrate that dominant, elite, rationalized approaches to heritage banalize heritage efficacies and can thus be termed a failed project. I argue that conceiving of heritage as a syndrome-and critically as a movement away from medical pathologization and towards a recasting of heritages as diverse constellations of cultural-spiritual magical-emotional experiences and engagements-better reflects the deeply felt complex and transformative practices at play. These heritage rites distinguished at points by those who wish their lives were more dramatic and those who wish their lives were less traumatic better describe how the vast majority of global actors engage with heritage, notably at popular, grass-roots level and in contexts of extremis, yet its significance goes largely unrecognized and unvalued.

KEYWORDS heritage, efficacy, Jerusalem Syndrome, well-being, magic, possessional acts 


\section{Introduction}

The Jerusalem Syndrome (JS) is the term coined to describe typically temporary (although for a small minority permanent) 'episodes' experienced by some visitors to Jerusalem, who on first encountering the city feel compelled to perform spontaneous 'uncharacteristic' ritual behaviours. Enacted in public spaces, these compulsive dramas are underpinned by an urge to deliver a redemptive message by which the world will undergo transformation and cure through the articulation of a vision of a 'just' future (Bar-el, et al., 2000).

The JS phenomenon elicits paradoxical responses. Some regard it as a sudden and extreme form of religious expression synonymous with intense experiences of spiritual 'well-being' (van der Haven, 2008). However, the JS has been featured in the British Journal of Psychiatry as a serious psychiatric concern and is designated as a 'pathological illness' synonymous with harmful experiences of 'psychotic decompensation', 'delusion', and 'depersonalization' (Bar-el, et al., 2000). In the most 'florid' cases this leads to 'sufferers' being sectioned for treatment the city's psychiatric facilities, notably that of Kfar Shaul (van der Haven, 2008: 114). The Rough Guide, with a comedic edge, dubs Jerusalem a 'schizophrenic city', depicting JS 'sufferers' 'wandering the streets, dressed in the robes of their adopted persona', of which 'Jesus is the favourite, but others include Moses, King David, John the Baptist and the Virgin Mary' (Jacobs, 2009: 42). However, different severities of the JS have been defined as typologies from I to III, the most pronounced cases leading 'sufferers' to identify with an iconic religious figure (typically as featured in the Old Testament). As such, 'sufferers' regard themselves as specially ordained prophetic, messianic messengers.

It is the clinical case studies of 'pure' JS that have raised the most controversy, as even travelers who without any previous mental health concerns may nevertheless 
succumb to Jerusalem's efficacies. 'Sufferers' display 'symptoms' that collect around ritualized behaviours, exhibited in 'seven clinical stages':

1. 'Anxiety/agitation' [...] 2. Declaration of the desire to split from the group/family and 'to tour Jerusalem alone' [...] 3. Obsession with the 'need to be clean and pure'. 4. Preparation of a 'white [...] toga-like gown [...] often with the aid of hotel bed-linen'.

5. The 'need to scream, shout, or sing out loud psalms, verses from the Bible, religious hymns or spirituals'. 6. A 'procession or march to one of Jerusalem's holy places'.

7. Delivery of a 'sermon' in a holy place 'usually very confused and based on an unrealistic plea to humankind to adopt a more wholesome, moral, simple way of life'. (Bar-el, et al., 2000)1 My quest is to critically position the JS as a 'Heritage Syndrome' (HS). This offers a unique means to apprehend the efficacies of heritage. Efficacy is expressed in various ways and forms. In the case of the JS, what is materialized as agency and revealed as potent heritage is place, thus an affirmation of Jerusalem's accolades as salient loci and its deifications as axis mundi, hierophany, and numinous (Eliade, 1987). Situated within both the 'zone of the miraculous' and the 'zone of absolute reality', Jerusalem is effectively positioned as more 'real than real' (Eliade, 1987). It emerges as a loci capable of acting on and possessing persons, thus challenging the routinized view that persons possess place. The JS also demonstrates that such efficacies encompass the broader dynamic of what it is to possess or be possessed by heritage. By reframing these possessional acts as efficacious techniques acting on something, or by extension to techniques of the subject on the person (cf. Mauss, 1973 [1936]; Lemonnier, 2012: 14; Warnier, 2009; Weiner, 1983) one can better understand how material agency reveals the potency of the subject/object and/or other articulations and expressions of charismatic potency, notably including 
'empowered' heritage capable of communing/fusing with the 'divine' (Byrne, 2004: 19). My argument draws out the particular associations of efficacies with experiences of collapse and subsequent ideas of making, forming, and creating. Ritual efficacy is directed towards creating conditions for life and lifeways, and for dealing with that which breaks or transforms them. Life as vitality, fulfilment, and as more 'real than real' is grasped at and thus formed through acting on materials, places, and persons to protect them. JS rituals, involving stages of cleansing, processing, and sermonizing - whether judged as either benign or malign — are part of the central paradox that sufferers claim to experience and to be trying to resolve. JS as 'cognitive dissonance' is understood as the emotional consequence of the pilgrim-tourists' 'idealistic collective subconscious image of Jerusalem' coming into conflict with the 'reality of modern city' (Bar-el, et al., 2000). Well-being and sanity thus depend on the capacity to bridge 'real' and 'imagined' Jerusalems by means of JS rituals. What interests me is how acts of possession claim to bridge the gap in the experience of the imagined and the real, and how the issues raised by JS crystallize the intimacies between heritage, health, and movement (notably displacement and place-making) as part of dramas of depersonalization and attempts to recover or remake worlds. Moreover, a diversity of 'heritage Jerusalems' and 'Jerusalem heritages' are created in the sense of the crisis/drama of possessing, resisting, and redeeming it, or being possessed, resisted, and redeemed by it.

My conviction is that these complex, dynamic, and transformative possessional acts (as engagements/struggles with possessing and being possessed) better describe the experiences of how the vast majority of global actors engage with heritage, notably at the popular, grass-roots level, yet its significance goes largely unrecognized 
and unvalued. A distinction emerges at points between those who wish their lives were more dramatic and those who wish their lives were less traumatic. Perhaps, then, here resides the crisis of well-being/ill-being that a critical understanding of the JS exposes - that is, the efforts of those experiencing unexpected emotional intensity or psychological duress to seek a cure by using fantasy/phantasy (Rose, 1998) as a shelter, refuge, coping strategy, and/or as a form of alternative identity-work. Freud, for example, argues that the delusional formation which we take to be the pathological product is in reality an attempt at recovery: a process of reconstruction (Freud, 1984 [1936]: xii, 70-71). In this sense heritage-work is bound up in imaginative, creative responses to help protect one's well-being and to deal with and potentially manage experiences of dissonance, destabilization, and transformation. Again, the attempt to deploy coping strategies - whether failed or successful, healthy or harmful - is part of the JS paradigm. Modernity's carers - including health-care and heritage institutions-are implicated in the formulation of authorized 'cures' and 'treatments' (whether by inscribing and thus valorizing/protecting selected heritage forms, or in prescribing psychotropic drugs) in interventions that categorize certain states of being, behaviours, and desires as 'normal' and others as 'dysfunctional'. As such, they in turn have the potential to inflict further acts of 'disembedding', 'depersonalization', and 'derealization' on 'sufferers'. Ultimately, the authorized position is that the only cure for the JS is to leave Jerusalem immediately. By revealing that complex, inextricable links exist between heritage efficacies and well-being/ill-being, our JS case underlines the ambivalent, over-determined, 'pharmakonic' quality of heritage (see Butler, 2011; cf. Derrida's concept of 'poisoncure'). As such, these transformative efficacies include the potential for violences and iconoclash in which quests for redemption, magical, and catastrophic thinking 
collide. 2 In its extremes this posits important questions about heritage efficacies: can heritage possess persons in ritual therapeutic acts of redemption and cure? And can it send otherwise 'normal' people 'mad' and cause harm? With these questions in mind, can the concept of heritage syndromes be used to radically problematize 'normalcy', and what we understand by heritage itself?

\section{Syndromes}

The Oxford English Dictionary states that a 'syndrome' typically refers to a 'condition' characterized by 'a set of associated symptoms', often regarded as synonymous with dysfunction, illness, and, as in the JS, mental disorder. However, it was not until 1955 that the term was used in a psychological sense. Alternative 'nonpsychologized' usages exist that characterize 'syndrome' as a psycho-social phenomenon (cultural-existential-spiritual-religio-magical, etc.) and as collection of 'opinions, emotions and behaviours'. The term also encompasses a 'concurrence' of symptoms, a 'concourse of people', a 'running together', and a 'place where several roads meet'. Interestingly, prior to centring within bio-medicalized discourse, the earlier meaning of 'pathology' was a 'study of the passions'.

Pursuing the significances of the latter pathways — rather than pathologizing them-offers a means to critically approach the condition(s) of heritage as a collection of 'symptoms', or, perhaps better, as dynamic and transformative constellations of heritage efficacies. My interest is in how certain symptoms/conditions/concurrences and behaviours are authorized and essentialized as part of heritage orthodoxy, while others are excluded, repressed, discredited, marginalized, and otherwise rejected. In this process efficacy is banalized, which obscures not only the transformative potential that accompanies the lived experience of heritage encounters, but also the practical, ritual means to re-engage and repair relations 
with self (selves)/world(s)/other(s), through processes of heritage-making.

Therefore, heritage that is oft pathologized (and thus banalized) in exclusive terms as rational, scientific, objective 'truth value' can be otherwise recast. In trying to grasp what a 'syndrome' might mean, diverse and transformed visions of 'syndromes', and therefore heritages, emerge. These may take the form of salient practices, places, objects, persons, substances, ideas, beliefs, aspirations, and desires, and also as a concurrence of 'opinions, emotions, and behaviours' as a 'study of the passions', amongst a myriad of possibilities. The distinction therefore needs to be made between the rejection of the forces that pathologize cultural and spiritual behaviours, and a coexistent wider call for a more diverse understanding of heritage practices/ syndromes.

In turn, this connects to how possession is realized in desire for heritage and acted out in lived experience. Heritage understood as ritualized 'sacred dramas' (Butler, 2007) creates loci to affect cure and healing which, as in the JS, may be linked to encounters with the 'unexpected'. Expressed variously as faith, mystery, curiosity, promise, wonder, escape, adventure, activism, pleasure and play, and so on, it is underpinned by possible encounters with dread, horror, threat, suffering, and madness. Moreover, this perspective on empowered heritage is bound up in often fevered quests that are synonymous with magical thinking, whether prophetic, catastrophic, and/or a form of wish-fulfilment.

I am thus interested in how these dynamics are materialized in physical, spiritual, psychological, and other ritual possessional acts associated with the experience of engaging with potent heritage forms. These may not involve any radical distinctions between heritages and other experiences classified as magical, spiritual, or revelatory. Crucially, as a model or template such efficacies are twofold. They are 
bound up in dramatic experiences of collapse/disintegration - both in terms of physical collapse and of personhood - and in the experience of dominant ways of knowing and of categorizing self/self-group, other(s) and world(s). Moreover, they simultaneously respond - successfully or unsuccessfully - to ritual creative acts of destruction and world-making that are synonymous with ideas of renewal, repair, and remaking.

While such heritage efficacy can provoke the response that this is a phenomenon concerned with religious desire rather than for heritage per se, critics have argued that the JS and related 'significant or well-known place syndromes' such as Stendhal Syndrome, Whitehouse Syndrome, and Paris Syndrome (Bar-el, et al., 2000) include notable 'secular' sites that transgress or deny the secular-religion binary. Such experiences prove more affecting at historical and symbolic sites where spirit of place is manifest, often in material form as 'noteworthy' monumental physical heritage. Equally, mainstream heritage discourse needs to grasp its responsibilities by moving beyond its still heavily secularized 'ego/self'/'persona'. As potent 'sacred dramas', an initial duality is revealed in heritage as a form of double-consciousness. One can frame this as a quest to possess and be possessed by a 'greater Heritage' (capital $\mathrm{H}$ ) of transcendent, iconic, auratic forms, as perhaps divine, cosmic, magical, mythical and archetypal patterns capable of Grand Narrative Redemption. However, present too are more mundane realities of a 'lesser heritage' identified with everyday rituals of care and protection. While 'greater Heritage' can be seen as that which the JS seeks to control, manage, and banalize via its pathologization and rationalization, 'lesser heritage' is akin to a broader understanding of heritage syndromes. What interests me is that these two pathways collapse and converge in lived experiences of heritage-work, thus generating 
complex and creative cosmologies of care and protection.

What disembeds, unites, and brings some levelling to these projected 'greater/ lesser $\mathrm{H} /$ heritage' pathways/concourses/concurrences are that, as possessive ritual acts, their commonality is that they offer a means to grasp diverse strategies vis-à-vis encounters and struggles with 'big questions' in the midst of life (Sontag in Cott, 2013: 12). These may be utilized as fantastic escapes from 'reality' or perhaps prove efficacious because of failed engagements that set in play attempts at repair/redemption. These strategies have the potential to be manifest as empowered attempts to transform the 'real-politick', for example, through appeals to ideals of social justice and its operational-experiential-ethical acting out on the ground. The will to grasp 'greater Heritage' can be identified in highly bureaucratized UN/ UNESCO 'sacred dramas' that are played out in the ritual acts synonymous with what have been dubbed 'UN Spectaculars' in which states-parties, as representatives of the international community, act out symbolic displays of unity and reaffirm their 'sacred duties' to UN agendas of world peace, human/cultural rights, internationalism, and so on, on the 'world stage' (Cruise O'Brien in Butler, 2007: 104). In more grounded fashion, UNESCO's listing of World Heritage as a mapping of sites of 'greater Heritage' is also a ritual possessional act and 'sacred drama' (Butler, 2007: 104-06). Of greater interest to me is the presence of alternative 'sacred dramas', such as Agamben's (2008) thesis of 'homo sacer', in which heritage is turned to as the transformative efficacious force and as effective cosmologies of care and protection by those in extremis (see Butler \& Al-Nammari, 2016). Typically, these turns to heritage form part of the struggles to be more than 'bare life' and are typically experienced in contexts marked by the uneasy concurrence of mundane everydayness and that of radical suffering that play out in the violent disembedding 
of life (Butler \& Al-Nammari, 2016).

\section{Efficacy debates}

The triad of efficacy, possession, and sacred dramas constitutes the framework of heritage syndromes/constellations by which an aspiration to grasp the unknowable is acted out, both in the grand narrative sacred dramas of 'greater Heritage' and in what I recast as practical heritage magics of 'homo sacer'. By bringing together heritage and efficacy, I wish to better understand how such efficacies are materialized in ritual acts, encompassed by the broader dynamic of what it is to possess and/or be possessed by heritage. Here I follow the work of Mauss (1954) and more recently Warnier $(2007 ; 2009)$ on magic and religion as techniques or practices endowed with efficacy. Also, significant here is Stoller's (1997) sensuous ethnography of magical practice.

For Mauss (1954), religion and magic could be treated like any other technical action if shown to have an effect on the body or the mind of the subject. Here, his remark that 'technical actions, physical actions, magico-religious actions are confused for the actor' resonates (Mauss, 2006 [1943]: 82). What Mauss wanted to deny was the rational separation of matter from subjectivity, and to make magic a form of efficacious action that was not a 'primitive' mentality but a legitimate feature of modern life. As an assault on the common belief that the secularization of modern life-worlds has made magic erroneous/problematic and little more than a charming survival of 'traditional folklore', heritage value has not deterred belief in the capacity to influence subjectivity. On the contrary, it denies the secularizing thesis whilst at the same time recognizing that it satisfies the wish to act on the world by also denying and/or collapsing the transcendent/immanent dichotomy. Efficacy debates like this highlight a central paradox in that the promise of heritage 
as an encounter with transformative forces is a complex experience that destabilizes, disturbs, and disembeds core categories and boundaries. As we shall see, these destabilizations in turn challenge routinized versions of heritage; rather than heritage becoming constituted within modernity as ruptures of the past, quite the reverse seems to be operating in the cases I pursue. Rather than re-embedding the spiritual in the immanent worlds of the everyday, practitioners who embark on examination of the JS see heritage as transcendent. They do so not merely to oppose the various materialisms from which they make a temporary escape, but to assert a form of the transcendent that often lies outside the realms of institutionalized forms or regimes (be they religious or secular). As such, I argue that 'heritage questing' (as literal journey and/or inner experience) is rooted in the desire not simply to aspire to or articulate a better future, but to empower oneself/self-group in the present. The promise of heritage efficacy lies, therefore, in the struggle to achieve what can never be known but merely sought in various acts of 'displaced grasping' at the invisible. It is as three pathways to such a 'land of promise' to which we now turn.

In these 'heritage quests', the first pathway - the 'west' travels 'east' to Jerusalem - offers insights into the patterning of 'greater Heritage' and to the cultural-political symptomologies operating alongside increased medical pathologization of certain behaviours. However, the West's will to authenticate and possess salient sites across the globe in the name of modernity/civilization and enlightenment/ scientism is a journey beset by confrontations/disturbances that reveal the limits of this project. Pathway two takes us from Jerusalem to engage with localized heritage efficacies within the wider Palestinian territories. As a place marked by occupation and extremis, my focus is on alternative 'sacred dramas' of 'homo 
sacer' and the presence of magical, pharmakonic, and transformational modalities of ritual engagement. In particular, the efficacies synonymous with being possessed as located in amuletic heritage and experiences of jinn possession embrace the potential to articulate otherwise 'forbidden'/'hidden' thoughts and alternative 'truth values'. This is achieved by opening-up the complex convergences/concurrences in more particularized heritage formations and by collapsing the boundaries between greater/lesser dualities to reveal alternative cosmologies of care and protection. My final pathway focuses on the 'Refugee Syndrome' (RS), which I understand as the antithesis of the JS. While the latter is a pilgrimage quest to commune with to possess/be possessed by - that which is efficacious, the former is an antipilgrimage of enforced displacement that breaks/distances persons from their efficacious centre/home/origin. I argue that, in the current climate, critical heritage discourse needs to be responsive to the needs of such constituencies, not least in that such experiences radically transform official routinized heritage practices, in terms of an urgent need to rethink underpinning ideas/ideals, moral positioning, and crucially the will to act and act back.

\section{Pathway one: Athens to Jerusalem}

I begin my quest to grasp the efficacies of heritage by taking a route synonymous with the 'western' pathway 'east' - a movement from Athens to Jerusalem — by following in the guiding footsteps of three intellectual figures - Freud, Arendt, and Sontag - whose diverse encounters with Jerusalem (literal and metaphorical, rejectionist and/or as embrace) proved salient to their work. These open up the potential to grasp connectivities between heritage, well-being, ritual movement, and efficacy, and their value in terms of meaning and action, notably in Arendt's (1978) case by evoking the 'obligation to think'. Crucially, too, they illustrate that 
the dominant 'western', 'orientalist', colonial crusader-settler aspiration to possess Jerusalem and thereby 'cure' its own madness is a failed project, subject to disturbances, disembeddings, and the unexpected break up of worlds/identities and magical chiastic inversion (Butler, 2013).

First to Freud, whose visit to the Acropolis and consequent 'disturbance of memory' has been categorized, like the JS, as a key example of 'well-known/significant place syndrome' (Bar-el, et al., 2000). Freud's 'therapeutic travel' (Rolnik, 2012) and his 'long held dream' to commune with Athens and the Acropolis contrasts with his aversion to and rejection of Jerusalem, which he never visited. No doubt Freud's pilgrimage to Athens as the icon of Greek heritage was in line with his claim to possess scientific credentials for the new discipline of psychoanalysis (Freud, 1984 [1936]: 443-56). This desire, in turn, is part of the wider possessive urges of modernity that form part of the shift from the religious to scientific secular paradigms and that position scientism, rationalism, and secularism as the 'royal road' to the fulfilment of 'progress', 'wholeness', and 'civilization' (Freud, 1984 [1936]: 443-56). While breaking with religious tradition, modernity's 'fathers' of progress simultaneously repossess the efficacies and cosmologies of care that were previously the preserve and responsibility of religious institutions. Thus, new enshrinements and sacralizations of the couch, the clinic and the academy, the archaeological site, monumental heritage, museums and collections, form part of a public-private network of exhibitionary and archival complexes. At the core of Freud's and 'western' modernity's own well-being and efficacy is the question of how these heritage sites - Athens and Jerusalem — relate and/or are supposed to interact. Wider still, this pathway offers a means to put a new twist on the question of 'What has Athens to do with Jerusalem?'. This enquiry, first 
raised by Tertullian in the third century AD, concerns the relation between Athens as the epitome of secularity and the learning of the philosophical Academy, and Jerusalem as its antithesis, as the symbol of spirituality and commitment to faith and religious thought.

Freud's rejection of Jerusalem is an affirmation of his views on its capacity to overturn 'normalcy' (as he would see it of rational and reasoned behaviours), an opinion reiterated by psychiatrists in their own rationalized scientific diagnosis of 'pure' JS as a clinical pathology. By categorizing Jerusalem as 'pathogenic factor' (van der Haven, 2008: 115) (a contamination/poison), Freud's vision of Jerusalem is legitimated as a 'strange, tragically mad land', led by the quest-pilgrimage to commune with the divine, and to be possessed by 'sacred frenzies' that motivate the acting out of 'presumptuous attempts to overcome the outer world of appearances by means of the inner world of wishful thinking' (Freud to Stefan Zweig, cited in Elon, 1991: 238). As such, Jerusalem is dangerously 'unreasoned' and 'unrepressed' and is regarded as genus loci - hierophany - synonymous with an excess or overdetermination of emotion and/as a possessional force of energy. It is worth remembering that to Freud all religion is variously neurosis, psychosis, and/or 'madness'. However, it is Freud's experience of visiting the Acropolis that paradoxically exposes the limits and inevitable collapse of modernity's boundary-making project and its categorical statements on 'reality/fantasy'. His encounter with this iconic Greek heritage provoked a splitting of sorts - a double consciousness - that he couched as a 'disturbance of memory'. This 'disturbance' is articulated as an encounter with the 'unexpected' - that provokes a 'splitting' and 'sharp' sense of 'astonishment' (manifest as a simultaneous and paradoxical expression of belief/disbelief) at the 'reality' of the Acropolis and of his proximity to this potent 
place that marked a 'break' in rational response (Freud, 1984 [1934]: 443-56).

This 'puzzle' continued to perplex him for the rest of his life, as it still does his critics. While Freud ultimately categorizes and rationalizes the 'event' within the scientism of his psychoanalytic framework, as an episode of 'de-realization' and bound up in Oedipal feelings of guilt (successful 'wish-fulfilment' that brings recognition that he has 'surpassed' his father), he saw it as a rupture that was significant enough to prompt a profound depth of thought and reflection capable of 'accessing the unconscious' (Freud, 1984 [1934]: 443-56).

Freud's account of the event can be used to place the heritage psyche on the couch and offer a succession of insights into heritage efficacies. With echoes of the JS, here, heritage desire (in Freud's case his conscious desire to possess Greek heritage as Enlightenment thought) collapses, giving way to reveal his conflicted attitudes (notably towards his Jewish heritage) and becomes synonymous with him adopting alternative 'iconic', 'mythic', and 'Old Testament' personas/identities (Oedipus, Hannibal, and, in particular, Moses), and consciously recognizing not only the pleasure and fulfilment, but also the guilt, anxiety, and depression at stake in such encounters with the 'real' (see Sugarman, 1998). Thus heritage can bring both satisfaction and/or terror when encountered as 'wonder' or 'curiosity' (i.e. often experienced as extremes of scale such as the gigantic and the miniature), or as a means of re-encountering the known as unknown (i.e. the Acropolis as iconic image experienced for the first time as a 'real' proximate place). It is also a means by which to grasp 'wholeness' (the sense of communitas/communion with 'universal', 'cosmic', 'archetypal', 'historical', and/or 'mythical' structures) (Sugarman, 1998). Freud reiterates that such encounters collapse the binaries of belief/disbelief, mind/body, persons/place, truth/fiction. As a consequence, temporalities shift and de-realization 
and de-personalization follow. In this sense the 'western' vision of Athens versus Jerusalem

is 'disturbed' and 'broken apart' by the acknowledgement and recognition

that categorical thinking cannot contain the efficacies of heritage.

Heritage as a metaphor of life

Freud's 'Jerusalem(s)' illustrates the paradox that a commitment to rational discourse and, in his case, fear that psychoanalysis would never reach the 'promised land' of evaluative reason but be condemned as Jungian 'mysticism', can alternatively be recast as a critical comment on 'western' binarisms that reduce transcendence to rational healing and cure. Other critics - Arendt and Sontag - have grappled with 'Jerusalem' efficacies in salient encounters that take these critical tensions and disruptions further. The work of these two intellectuals open up alternative pathways to engage with the efficacy of heritage and its relationship to possessional acts. Their respective articulations of thinking as akin to the 'sensation of feeling alive' and as a movement in which 'when the mind reaches out to know, the space of desire opens' (see Cott, 2013: 12) offer a means to rethink the JS as an 'opening up' and 'reaching out' of heritage discourse and to reclaim heritage as a 'space of desire'. Such a space is one in which 'feeling and thought', 'known and unknown', 'immanence and transcendence' collapse and mingle, and in which wonder, magic, ritual incantation, and so on, are experienced as potentially graspable epiphany-like events. This pathway similarly disembeds metaphors of museological-heritage forms as deathly musealizations by opening them up as potent, generative metaphors of life/life-forces/life-worlds.

Both Arendt and Sontag made journeys that led to them to possess/be possessed by the pharmakonic efficacies of Israel/Palestine. Arendt's experience reporting for the New Yorker on the Eichmann trial in 1961-a powerful ritual act symbolically 
and purposefully performed in Jerusalem - leads to her famous (and controversial) thesis on the 'banality of evil' (Arendt, 1994 [1963]) that formed the point of origin for her book The Life of the Mind (1978). This theme of banalization, versus the critical dissolution of accepted institutionalized drives of categorization and interpretation, connects Arendt and Sontag. Here I want to take up Sontag's argument in her seminal essay 'Against Interpretation' (2009 [1961]) and related film Promised Lands (1975).3 In the former, Sontag begins by musing on the earliest 'experience of art', the efficacies of which continue to cast its potent magics and incantations on the popular imagination. I would argue that the 'experience of heritage' and the promise of fulfilment bound up in heritage encounters similarly persist, and its magics and incantations continue to occupy an enduring place in motivating popular4 ritualized responses that in turn resist banalization in terms of modernity's on-going rationalizations, secularisms, scientisms, and categorizations.

Sontag's defence, and her reclaiming of the desire for art/heritage as transcendental life force, corresponds in turn to her campaign 'against' the drive toward dominant elite forms of 'interpretation', which she considers to be the locus point of modernity's banalizations. She argues against critics and practitioners who persist in defining art and its meaning via categorizations of 'value' based on the question of what is it (its definition/classification) rather than the experience of what it does (its efficacies), in terms of provoking transformational engagements. Sontag insists that this ultimately leads to an 'impoverishment' and 'depletion of our world' (Sontag, 2009 [1961]: 5). She uses this thesis as part of the filmic documentary-style of Promised Lands to draw out the ways in which militarized rituals of violence deplete and impoverish victims, perpetrators, and place, and to argue for the need to pluralize - in terms of co-existent alternative visions - cures, experiences, 
and life-worlds.

Her insight that '[T]he two things that spiritual values have become attached to since the collapse of religious faith are art and illness' is crucial here (quoted in Cott, 2013: 42). The contemporary emphasis on heritage and/as well-being is implicated in this crisis, too, in the form of periodic interventions that claim a 'social', 'therapeutic' use value in 'culture as cure' as part of regular attempts to redeem heritage anew. Arendt's iteration of an experience of 'wonder' as the origin of philosophy but, more importantly to her, as that which sets in play the act of 'thinking', thus sees the opening-up of the human condition as a movement away from 'unworldliness' (that of philosopher's cave or totalitarian 'reality') that is enacted within the dynamic 'world of appearances' (cf. the crucible of new creative possibilities for self/self-group/worlds) (Arendt, 1978: 143-48). Her description of 'wonder', like that of value, is again something indefinable, and its efficacy lies in that it cannot be defined or interpreted but has to be grasped, felt, or experienced. Arendt also argues that the underside of 'wonder' is 'horror', which causes the same 'awe' and as such must be submitted to 'thinking'. There is, however, an important point of recognition which again challenges routinized understandings of 'fantasy/reality'. For Arendt, there is no reality to be found in the philosopher's cave, nor in the so-called 'truth-statements' and 'reality' that totalitarianism articulates (Arendt, 1978: 143-48). She also makes clear that the experience of 'wonder', like that of the JS and spiritual ecstasy, can also be traumatic (i.e. cause de-personalization/de-realization that can be synonymous with either well-being and/or ill-being). Within modernity's banalizing forces, however, the 'spiritual' is repossessed and categorized by 'experts', notably as 'aesthetics'. The routinized UN/UNESCO-led heritage discourse can equally be seen as a depletion and banalization 
of 'wonder' as its efficacies are reframed in the problematic category of 'Heritage

value' (again with a capital ' $\mathrm{H}$ '), notably as fixed within the criteria of

'Outstanding Universal Value'. I would argue that, while contemporary claims

(including those of UNESCO) to 'social' values, 'living' heritage, 'intangibility',

and 'spirit of place' 5 are synonymous with new categorizations linked to objectives

of inclusion, these continue to be at the cost of a force of banalization which rejects

common experiences of the value and efficacy of heritage: those that resist reductionism, interpretation, and definition.

Pathway two: across borderlines - practical heritage magics

Alternative quests for the 'promise of heritage' take us across boundaries and into the occupied territories of Palestine. In a 'situation' that emerged out of the historical and on-going colonial violences and the trauma of Al-Nakba in 1948, disturbing 'security rituals' predominate (cf. Weizman, 2007). They continue to generate violences materialized as malevolent symptoms: militarized zones, checkpoints, greenlines, and the notorious 'security'/'apartheid' wall. Objectified as 'facts on the ground', these create further acts of depersonalization/derealization that impact in diverse ways by collapsing everyday life and resulting in forms of extremis. Paradoxically, such obliterating rituals are contested in quests to repossess and 'act back' in salient heritage practices that pervade Palestinian life-worlds and continue to be communed with and reconfigured in resonant ways. Here my alternative journeying follows in the footsteps of Dr Tawfiq Canaan (1882-1964), a Palestinian 'nativist intellectual' (Tamari, 2009),medical doctor, polymath, and pioneer researcher of 'Palestinian popular heritage' (al-Ju'beh, 2005: 103) and collector of over 1400 amulets and talismanic objects. I subsequently make a pilgrimage like many before me-including anthropologists Granqvist and Rothenberg 
- to the alternative genus locus of Artas: the 'Home of the Jinn' (discussed below). My passage culminates in drawing out the shared efficacies of intellectual calls to 'take seriously' the deployment of practical 'magic(s)' in the contemporary global arena and the spread of 'archive' and 'heritage fevers' gripping Palestine in what is argued to be epidemic proportions (Butler, 2011; Doumani, 2009).

First to Dr Canaan - a liminal figure - whose various personas and networks take our quest beyond Jerusalem's grand narrative and sacred geographies and into more informal heritage economies. To some extent unseen or hidden in West Bank Palestine, he engaged with alternative popular concurrences in the efficacy of persons-things. The titles of Canaan's publications indicate the variety of popular animate and magical heritages that caught his interest, for example, Haunted Springs and Water Demons, Mohammedan Saints and Sanctuaries, Superstition and Folklore about Bread and Arabic Magic Bowls (see Tamari, 2009: 24). As a biographer states, Later on he begins to investigate the relationship between folk religion, magic, madness, and superstition. He collected a huge number of amulets and fear cups (taset al rajfeh)mostly in lieu of payment for his treatment of patients in his frequent tours of rural Palestine.

(Tamari, 2009: 24)

Canaan's legacy - the product of an encounter between bio-medical cure and popular healing - frames him as a liminal persona, connecting alternative approaches for protecting well-being and preventing ill-being. Crucially, these popular forms are characterized by belief in and their engagement with spiritual/supernatural/efficacious forces that act ambivalently — pharmakonically — as both benevolent and malevolent agencies. What this popular search for the efficacy of heritage in spiritual forms promises is the fact that they are underpinned 
by a conviction that these modes of enchantment will reveal, 'explanations and answers for "the inexplicable"' (Parish, 2007: 169), on the basis of grasping heritage as an 'overdetermined' force that requires being grounded in rites/ritualized acts.

\section{Home of the jinn}

It is these efficacious rites that takes us to the alternative genus locus of the village of Artas, near Bethlehem. Within folkloric wisdom Artas is the 'origin' and 'home of the Jinn', and we follow in the footsteps Dr Hilma Granqvist, a Finnish anthropologist who undertook studies of spirit possession by jinn in the 1920s, and Dr Celia Rothenberg, who trod the same research path in the 1990s to update Granqvist's findings. A significant aspect of this research was to not only highlight the continuity but renewed belief and experiences of jinn possession. The Arabic word jinn comes from the verb 'Janna', to hide or conceal. Jinns are thus understood as invisible forces - some have religious belief and are regarded as 'eminently social creatures, living in a world parallel to our own, invisible to us, and able to see and enter our world freely'. Such spirits act as either good or bad forces in attempts to influence humanity: thus curing and/or causing human ill-being/well-being (Rothenberg, 2004: 39).

In an alternative twist on the pathologization by psychiatrists of JS as dysfunctional 'personality disorder', a radically different understanding of spirit possession emerges. Here, a person who is 'possessed' is understood as being 'worn by' or 'wearing' a jinn/spirit (Rothenberg, 2004: 2). In this indigenous framework, the 'externalized social self' and 'identity' is understood to be 'eclipsed' or 'subsumed' by the jinn. In some cases the malevolent jinn would bring harm and madness. Thus being clear not to romanticize or deny the abuses and violences that can and do emerge in some experiences of possession, Granqvist and Rothenberg both 
argue that jinn are often regarded as complex and powerful resources for resisting dominant hegemonic discourses.

As such, they argue that these experiences are a valued means of grappling with the complexities of everyday life, adversity, and extremis and are attempts to manage losses both 'large and small', including threats to honour and dignity, and increasingly as a means to respond to on-going occupation and conflict (Rothenberg, 2004: 2-6). Rothenberg notes that jinn possession and the ritual acting out of these experiences often provides a 'safe outlet' by which gendered and unequal power relationships could be expressed and productively reach mutually beneficial conclusions. As such, 'Jinn stories direct listeners to experiences and understandings that would otherwise not be said and remain hidden' (Rothenberg, 2004: 7-8). One example concerns a young woman possessed by a jinn. Her experience is the basis for recognizing that a newly arranged marriage is not accepted by magical forces and that the only way to dispossess the young bride-to-be is to select another suitor advocated by the woman herself. Only in such 'magical' circumstances could such an opinion be articulated and acted upon.

Here one can grasp alternative possibilities in terms of rethinking possession. With echoes of the JS, one of many such interpretations is of viewing the experience as a 'personality split' and a way of coping with severe stress by what is variously couched as a strategy of protection (including denial) by means of seeking refuge in fantasy/phantasy through the adoption of an alternative persona(s). The possessed person is thus said to have acquired an 'additional' identity often synonymous with the 'other' (i.e. Muslims being possessed by 'Christian, Jew, even Israeli jinn' (Rothenberg, 2004: 2-6)) that bring them into crisis. Symptoms include paralysis, blindness, and loss of voice. As my own ethnographies in the 
West Bank have shown, local, traditional healers often treat such symptoms via ritual recitation of the Quran, drinking water that has been blessed with a prayer, and/or herbal cures and remedies (Butler, 2011). Belief in jinn/spirits has met with certain onslaughts (e.g. increasingly radical Wahhabi Islam seeks to counter such beliefs) and ententes with the forces of secularization, scientism, biomedicine, and religion. Yet not only are the spirit of the jinn and use of amulets still a potent force at the family and local household level, but jinn possession has been harnessed by treasure hunters to search for archaeological objects. Here, heritage sites are also understood in the local perception as the potential residence of the jinn and as such are a haunted, abject space to be avoided (Al-Houdalieh, 2012).

Returning to my own ethnographies in the West Bank (Butler, 2011), alternative ritual modes of communing with efficacy continue to be advocated by local/traditional healers, be they Islamic sheikhs, sorcerers, magicians, herbalists and/or those involved in New Age practices. The interventions of Samaritan healers, for example, rely on practices of astrology and numerology, a repertoire of sacred texts, figures, substances, liquids, and signs used in the safeguarding of well-being. Of interest is that clients are typically Muslim and many are women. Clients are instructed to use (chant, ingest, pour, scatter, hide, position) material in rituals that are often centred upon the reconnection and/or disconnection with persons-objects. The latter ritual disconnection often relates to clients seeking efficacy in acts of retribution, while agendas of securing romantic attachments, family connectedness, and restoring fertility and prosperity are uppermost. Alongside these iconic personas one can see how persons establish their own more informal means to commune with that which offers efficacy and well-being: here one 
gains a sense of persons communing with their own efficacies, whether articulated as resources of inner faith and/or everyday sumud (steadfastness) (Butler, 2011).

\section{Global potencies}

In addressing this creative paradox, we need to explore how this 'turn to magic', like the 'turn to heritage', is a potent and on-going global phenomenon (see Appaduari, 2008). We must be aware that the inextricably linked forces of heritage magics pervade and destabilize the binaries of contemporary/traditional, peace/conflict, security/harm, and folklore/popular culture/urban myth, and so on. I follow Appaduari's

call for a 'deep and serious space for the idea of magic', which is based on the conviction that 'Magic is [...] the universal feeling that what we see and feel exceeds our knowledge, our understanding and our control' (2008). Here the popular spirit of living heritage is oft turned to resolve the unresolvable, particularly in circumstances that threaten the ruination of human dignity.

Magic is then 'a method for deploying modest technical means to address outsize ethical challenges', and is 'about what people throughout the world do when faced with uncertainty, catastrophic damage, injustice, illness, suffering or harm, while ritual (also magical in its logic) is performed to forestall or prevent these very things' (Appaduari, 2008). Echoing Sontag, Appaduari adds that it is 'the set of techniques that human beings have assembled to manage those risks which appear in the zone where the big things meet the little things, and when that meeting goes wrong'. Crucial here is the promise that, via the grasping of efficacy, persons have the ability to empower themselves or their self-group in the present.

The 'return' to both heritage and magic connects us to what has been dubbed the contemporary forces of 'archive' and 'heritage fevers' gripping Palestine (Butler, 2011; Doumani, 2009). Indeed, the Tawfiq Canaan Collection of Palestinian 
Amulets gifted to Birzeit University by Canann's family in 1983 has been revived under the very banner of 'Heritage Magic' and regarded as a valuable resource. Moreover, 'heritage magics' can be opened up to further potencies. Crucially, it offers new and alternative languages, lexicons, metaphors, and analogies that further destabilize heritage as a failed bureaucratic exercise in categorization and listing.

As such, the motif of practical heritage magic(s) continues to exert efficacies across North and South, in the sense that heritage questing reveals many alternative global heritage personas and identities at play. Here, for example, in a world of globalizing flow vampires, ghosts, monsters, sorcerers, magicians, and Dan Brown-esque revelatory texts are embedded in literature, film, and popular culture and perhaps less obviously inhabit and transfuse highly secular, political, and scientific realms (Appaduari, 2008; Franke, 2010).6 Perhaps like certain magics, the origins and influences from which they emerge may just be airborne. For instance, as in the controversial revelation that the magical persona of Harry Potter was influenced by Mahmoud Darwish's contemporary Palestinian poetry of resistance (see Armitstead, 2015). These magics are also found within the West's own genealogy. The semi-divine origins of museological-heritage discourse is itself entangled within the mythology of the divine muses of archaic lore. These muses exert their pharmakonic powers to possess persons-things-places and affect well-being/ill-being before a certain banalization of their personas took place. I couch this banalization as a preoccupation with 'form over force', another fixing of heritage value/efficacy as 'what it is' rather than 'what it does' (cf. Nancy in Butler, 2011: 363). As magical agents of inspiration and transformation who had the power to mesmerize and enchant, the Muses' efficacies create connectivities/concurrencies with other supernatural heritage 
cosmologies that are proven to be valuable to diverse contemporary constituencies.

For example, the feminist reclamation of muses and their transformation from passive poetic allegories to active agencies in terms of increasing the profile of female creativity, past and present, has offered frameworks of empowerment and repossession (Greer, 1996). The recasting of the saying 'when canon's roar the muses stay silent' has similarly been repossessed and challenged by numerous artists and writers in planning creative projects that support peaceful solutions to conflict and highlight the plight of communities that suffer in war - including a focus on the on-going war in Gaza.7 The Palestinian Jerusalem-born artist Ibrahim Al-Nashashibi has explicitly stated how the muses inspired his creative work: When I was 10 years old I read a book of Greek mythology that described the Nine Greek Muses, who were the daughters of Zeus and Mnemosyne. It was very inspiring to me and it helped me understand how ideas get into our minds. The Muses bring them to us. I thought, we don't have Muses here in Jerusalem but we need them. (cited in Bowen, 2012)

The Muses returned to inspire Al-Nashashibi in his first work painted thirty-three years later called 'The Muses of Jerusalem', created for an exhibition at the United Nations building in New York City. Interestingly, Al-Nashashibi's Muses wear the traditional Palestinian dress or thobe: an item at the core of salient Palestinian heritage constellations (see Butler \& Al-Nammari, 2016). He expands upon his particularization of the Muses:

I decided on having seven Muses instead of the nine from Greek mythology because there are seven gates to Jerusalem [...] So far, I have only been inspired to know three of the seven Muses [...] and the mother of the Muses, but I am awaiting further inspiration. 
(cited in Bowen, 2012)

Now living in the US following the displacement of the 1967 occupation of East

Jerusalem, Al-Nashashibi continues to create art infused with Palestinian heritage

and insists:

I think that it is important that we go inside and explore ourselves. Everyday I discover myself anew. Inside of us we have a lot of secrets. The Muses help you discover them. It is like you are in a coma and are guided by the light. The Muses will show up and light your way. Their purpose is to enlighten people's paths. (cited in Bowen, 2012)

\section{Transfears/Transformations}

The contemporary Palestinian return to and respect and value for heritage is clearly more than archival. Quite literally, it is the recognition that the potency of heritage may be reactivated and still play a role that is unrecognized by the official 'classificatory' approaches that emphasize their representational quality only in terms of identity politics. Here, 'heritage magics' form a significant part in transformative acts since the experience of Palestinians as 'besieged identities' has been, and continues to be, that of enforced disembeddings: persons are transformed into internal refugees — paradoxically both displaced and confined — and/or as a global diaspora. The magics and pathways to well-being and dignity (discussed above) draw together various salient cultural forms and locales and heritage constellations/ concurrences, that engage with 'living', vital, popular, animate heritages of 'everyday life', and as such provide a means to cope with and attempt to overcome, subvert, survive in - if not transform - contexts of harm, threat, and extremis. Writ large, rethinking these and other cultural tropes of heritage, well-being, displacement, and possession is bound up with the need to take difficult pathways and to face the detours, denials, dead-ends, and disruptions ahead. It is also a journey 
subject to boundary crossings and attendant 'transfears' (Latour, 2011: 66), but crucially, too, the requirement to take on efficacy as strangeness/alterity/difference. The sense in which 'heritage-seekers' inevitably become 'heritage-makers' is captured in Latour's claim that 'migrants have reconfigured the wisdom of the passage' (Latour, 2011: 66). His concomitant calls for the need to 'import jinn' are thus part of a subversive efficacies of the movement of 'persons-factish'. Inverting the dominant discourse of pharmakonic poison-cure, he argues that 'migrants heal us' in the sense that they provoke engagements with 'differences' which 'are not there to be respected, neglected, or subsumed' but, echoing Sontag and Arendt, and quoting Whitehead, to act as 'lures for feelings, food for thought' (Whitehead cited in Latour, 2011: 66). The on-going impulse and need of all constituencies for heritage, as both critical lens and 'resource', echoes the JS as a 'bridging' practice and at its best heritage offers comfort, care, and relief from fragmentation and harm.

\section{Pathway three: refugee syndromes and heritage constellations}

My final pathway for understanding the efficacies of heritage and possessional acts addresses what I couch as the 'Refugee Syndrome' (RS). The experience of RS can be understood as the antithesis of the JS. While the latter is a pilgrimage quest to commune with - to possess/be possessed by - that which is efficacious, the former is an anti-pilgrimage of enforced displacement that breaks/distances persons from their efficacious centre/home/origin. It has initially at least much in common with the genre of 'non-place syndromes', the alter ego of the aforementioned 'significant place syndromes'. I hope, however, that van der Haven's assertion that 'the ambiguity of the experiences and behaviours of the Jerusalem Syndrome results in varying interpretations that reflect world view' (2008: 114) helps keep in play new and alternative heritage forms, personas, identities, efficacies, and 
other world/worldly views.

I begin my 'anti-pilgrimage' by following in the footsteps of 'failed' pilgrims to the outskirts of Jerusalem and the Kfar Shaul psychiatric hospital where many of those diagnosed as suffering from JS are committed for treatment (although the only true cure is to leave Jerusalem and return home) (cf. Bar-el, et al., 2000; Kalian \& Witztum, 2000). The hospital space is uncanny in terms of the 'perverse irony' of its proximity to the 'massacre site', formerly the Palestinian village of Deir Yassin. Thus, in turn, pharmakonic forces 'unearth' a largely hidden heritage synonymous with Al-Nakba, the originary event to which all Palestinian RS relate as do the on-going violences that followed (Coughlin, 1997: 317).

Such displacement from and within 'promised lands' compels us to take forward the obligation to think and grasp the complex ethical paradoxes of heritage efficacies, especially when displacement itself gives way to complex and sometimes unexpected pathologies and forces of harm. The RS at its most acute may be witnessed in Palestine as a 'refugee nation' bound up in a complex experience of containment, occupation, and unresolved displacement. Moreover, all refugees to a greater or lesser degree find themselves subjected to the same perceived needs - that is, the 'three standard solutions to refugee situations': 'integration, resettlement in a third country, or repatriation' instituted by international agencies (Chatty, 2010). Powerful though these perceived needs may be, acknowledging them also means that the displaced find themselves subjected to new, dominant regimes of care and confinement: for when displacement is reframed as humanitarian need its core objectives of relocation and replacement become top-down, routinized, bio-political 'rites de passage' in which humanitarian agencies such as the UN and their 'sacred dramas' intervene on 'behalf' of the displaced (Chatty, 2010). Again in an inversion 
of the JS, the refugee begins a transformation which, if return is deemed impossible, is confined to one possible future: 'rehabilitation' within 'a new lifestyle and persona' (Peteet, 2005).

What is often suppressed in the aid industry is the fact that these 'cures' can also carry significant poisons. For while a 'solution' demands not only an 'acceptance of displacement and denationalization', it can also essentialize the refugee condition as a 'pathology' or 'psychological disorder' (Malkki, 1995). Here, many dependent and disoriented refugees fall victim to the 'cornerstone of humanitarian and host state responses to an influx of the displaced' (Peteet, 2005: 28), namely the 'refugee camp', the solutional response for those displaced, whose social orders cannot be replaced. Indeed, herein resides the 'Palestinian paradox' (Peteet, 2005), for a pathology demands a 'cure'. And, while a 'cure' is sought, any aim by agencies to resolve refugee experiences through rehabilitation or return may encounter political forces that aim to maintain and pathologize them.

By essentializing a core legal right and reframing it as a political identity, social need, and an ethical imperative, the 'Right to Return' remains an important element - if not the key bulwark — for claiming justice. Due to the continued failure of peace talks, the situation creates a refugee impasse for Palestinians whose resolution may remain all but impossible. By default, this impasse/paradox offers a challenge to generalized models and routinized solutions of 'curing' displacement. A further paradox concerns the conflicting role of heritage in maintaining Palestinian refugee life, both in order to sustain the permanence of the 'temporary' nature of the refugee camp life itself and to potentially exacerbate the political consequences of dislocation (see Butler \& Al-Nammari, 2016). Here a certain engagement with the 'factness of diaspora' - a complex form of 
'affiliative self-fashioning' (Nelson, 2011: 23-26) -underpins/creates the efficacies of heritagization. With overtones of Latour's (2011: 12) concept of 'factish' (a hybrid of scientism's 'fact-objects' and magical 'fetish-objects' that ultimately act as amuletic forces), 'factness' is grasped as 'possessing the state, condition, or quality of fact, yet not being only or exactly fact' (Nelson, 2011: 25). Moreover, in terms of practical magics, refugee camps typically become potent loci for memorywork and repair as powerful archival and heritage spaces in which people are possessed or fevered, with the imperative to commune with lost efficacy and repossess lost homelands and anticipate possible futures via various materializations (Butler \& Al-Nammari, 2016). For some, enforced mobility has taken them to San Francisco, Riyad, or London, while those in refugee camps often shoulder the burden of establishing satellite 'little Jerusalems' or 'little Palestines'. Thus, being Palestinian often intensifies in a refugee camp with ritual acts of heritage- seeking and heritage-making similarly intensified.

To be Palestinian in these displaced/refugee contexts is increasingly an intensified 'virtual experience' (Hirsche \& Miller, 2011: 12) centred around certain ways of being Palestinian. These ways are ardently maintained over generations in camps with little or no physical contact with Palestine itself. This demonstrates that heritage possession becomes divorced from the ability to possess a place or site of heritage (the physical possession of being there). Instead, it becomes a matter of possessing identity as a form of 'virtual reality' in which the thing and its double become the same. Subjects and objects become part of an interchangeable continuum. Objects searching for subjectivity in digital archives, cyber-space, and social media are magical technologies of repair and compensation for absences and distancing of intimacies by offering virtual contacts/memories and quests for 
authenticity of Palestinian-ness.

The inability to return 'home' - to the 'ground of Palestine' - simultaneously creates 'sensory deprivation' (Taylor, 2011: 271) that increases desire to attempt to 'grasp' Palestine as sensorium - as touch, food, smell, taste, sound - and often prompts magical thinking and wish fulfilment. Crucially, fascinating objects emerge purposefully created to resolve and bridge this gap materially. These include an entrepreneurial shoemaker from Hebron who 'produced a shoe that contains a small amount of Palestinian soil in the sole', an object created to ease the 'despair of Palestinian refugees and deportees about ever setting foot on the soil of their country' by magically fulfilling this wish (Shehadeh, 2017: 64). Other forms of 'factness' prevail in the popular return and reworking of tradition and authenticity, for example, in the practice of Palestinian embroidery, dabka dancing, and new cultural expressions in rap music.

As such, my third pathway is a quest to 'grasp' a virtual promised land that relates to the way people not only hold on to heritage they can possess, but also reinvent it by transforming it into 'realities' that are ever more transcendent because it is impossible to foster forms of identity in a passive everyday/taken-for-granted sense. A process that for many creates affective idealizing and over-determined heritage value is constructed not only in order to cope with that which is unbearable within visions of a bearable - or 'just' - future, but to empower and change the present. Here the vision of Jerusalem made mobile - once the preserve of crusader colonials - and the ability to experience the efficacies of ' $N$ ew' Jerusalems is grasped at and realized by displaced communities. Here, too, the Jewish promise, 'Next Year in Jerusalem', is powerfully repossessed to articulate the specifically Palestinian desire for return. 
A vignette captures this in the popular practice of Palestinian refugees' quest to locate viewing places where it is possible to see the physical landscape of their homeland. For Palestinians in Jordan, the heritage sites of Um Qais and Mount Nebo hold a particular magical efficacy (see Butler \& Al-Nammari, 2016). The latter is particularly potent for being synonymous with Moses' beholding the Promised Land from afar. In fact, Moses is a figure/persona that pervades all the pathways journeyed so far. From JS 'sufferers' adopting Moses in his Messianic persona, to Freud and 'western' scientism (including UN/UNESCO), possessing/emulating Moses as Patriarchal law-giver and leader, to more popular empathies with Moses' alter ego as Magician. The ultimate affiliation with Moses vis-à-vis my third pathway is then with Palestinian refugees/ diaspora as persons denied entry to and/or mobility within the Promised Land.

\section{Conclusion: the banalization of critical heritage discourse}

My motivation for exploring these three pathways relates to critical heritage studies through the recognition that a theoretical basis has to be established for the future of the subject. Perhaps inevitably this has focused on the politics of heritage and the circumstances in which access to heritage relates to possession as recognition, identity, and rights typically enshrined in law and property. Whilst heritage critics have been able to assert the significance of heritage as an academic subject, its origins are typically couched within non-academic technicist scientism, and concerned mainly with questions of management and preservation. What is becoming glaringly obvious is that we have very little understanding of why the term heritage evokes such strong emotional reactions nor how its ritual practices offer such profound efficacies. The blending, infusing, splitting and animation of 'double' and/or multiple consciousnesses vis-à-vis iconic sites and 'everyday' life thus provoke magical, existential, ontological, 
spiritual, and supernatural cosmologies in quests that are variously expressed as a search for pleasure, play, adventure, escape, wholeness, and/or for answers, meaning, inspiration, contemplation, thought, and/or more sacrificial communion. And for many global constituencies these are fundamental for heritage rites to exist. In part, the problem is the 'banalization' of dominant heritage discourse. A typical genealogy locates the 'birth' of heritage as a practical concern in the rationalizing postWorld War II environment with technicist solutions addressing the fear of loss and resolving the destruction of cultural identity (see Butler, 2007). Notable here again is the UN/UNESCO-led globalization of Kantian cosmopolitics that sought to challenge, counteract, and thereby 'resolve' fears of re-emergent totalitarianisms and fascisms and, writ larger still, modernity's dislocations. Heritage has come to mean, therefore, the conditions in which preservation is prioritized as the 'value' that acts as a buffer not only against conditions of conflict and destruction but also the desire for locality in conditions of increasing homogenization and commodification. 'Heritage value' is symptomatic of this concern; we are increasingly pressured to demonstrate that heritage has a value that can be converted into an economic, or in a more general sense, social value (i.e. maintaining identity against conditions of erosion). Moreover, commodified heritage value is increasingly manifest in new conditions of threat and endangerment, notably anxieties vis-à-vis the Anthropocene. Heritage, in turn, becomes further embedded as a psychological-emotional-physical bulwark against erosion, and as such has an immediate valence in all sorts of development and future-oriented programmes.

Top-down heritage forms are a perfect example of the technicist argument that heritage - as constituted within the integuments of modernity - is an essential part of development. However, the ritualized technicisms of heritage often fail to recognize, 
value, or understand existing local heritage practices and efficacies. Again, heritage interventionism is often a promise that never comes or if it does arrives as a threat (cf. Basu \& Modest, 2015: 4; Escobar, 2011; Ferguson, 1990). Moreover, in the Palestinian/Israeli context, such technicist cures are synonymous with the pathologizing violences earlier rehearsed. These acts of border-making, notably fixating on the rights to possess Temple Mount/Haram al Sharif, also define globalizing structures of the 'peace industry' and 'heritage industry'. Moreover, proffered solutions such as the Camp David negotiations and related series of summits and talks are couched within the very discourse of the 'science-religion confrontation' that plays out in Jerusalem (and more broadly, too, in the Palestine/Israel conflict), as a violent zero-sum tragedy (Latour, 2005: 35). Conflict, deadlock, and death thus pervade attempts to possess the site, leading to the repetition of grand narrative clashes.

By way of contrast, the issue at hand should be how the power, potencies, and the diverse efficacies of heritage create an emotional sense of well-being which is currently largely ignored and 'unvalued'. These heritage practices operate across registers centring upon everyday aspirations for protection and joy, to ontological, spiritual, sacred, cosmological framings. I argue that identity is an innocuous term if left in the limbo of exclusionary politics and the rights culture. It does not relate to the actual experience of heritage, witnessed in the situations where attachment to place and things - and displacement from them - evoke the strongest sense of belonging and repossession. Heritage desire and possession is therefore oft related to the unobtainable - unachievable - but still the ideal is that this can be overcome. Heritage promises a resolution — through attachment to place/ thing and sense of love/care/life that it articulates. But the difference with the efficacies of heritage is its relation to the strange, alterity, othering, and so on. It is in this 
nexus that we have to understand why heritage has the power it clearly evokes to achieve a transformed sense of being and of acting in the world(s).

Through delineating three pathways, we come to understand how heritage belief contributes to a sense of realization, through acts of de-/re-personalization and de-/ realization, configured in the belief that through such experiences we may become better. Moreover, I argue that a contemporary radical reconceptualization of heritage is needed that is capable of recognizing that the dominant elite rationalizing and banalizing of such heritage efficacies, and their sacred dramas, is a failed project. Instead we need to realize that for many it is the 'efficacies of heritage' that evoke a sense of 'magical life-force' and that provokes thoughtfulness and promise the possibility that alternative values can be materialized in the present, and that along with enchantment, myth and ideals of well-being, these continue to pervade and persist in popular heritage discourse across North and South.

\section{Acknowledgements}

My thanks to Dr Jamie Larkin for his support and encouragement and to the anonymous readers for their thoughtful comments and positive suggestions. Thanks to Susan Bigmore for her help with the proof stages. This paper is dedicated to those in extremis, for whom the efficacies of heritage are often one of the few resources left open for the 'magical', and otherwise, creation of empowering 'facts on the ground'.

\section{Notes}

1 See van der Haven, 2008 regarding his challenges to this thesis.

2 Jacobs (2009: 42) describes, 'sufferers' committing 'bizarre acts' in readiness for the 'Second Coming', including an Australian in 1969 who 'tried to burn down Al-Aqsa Mosque in preparation for Jesus's imminent arrival'.

3 The film was shot in 1973 just before the end of the 'October War', released in 1975, and banned in Israel. 
4 Following Arendt and Sontag, I am conscious any endorsement of specific practices partly for being 'popular' must take into account debates on 'the people', 'popular', 'populism' (cf. Laclau and Mouffe and their critics).

5 See the values enshrined by UNESCO: http:// unesco.org and the FARO Convention: http://

www.coe.int/t/dg4/cultureheritage/heritage/Identities/default_en.asp.

6 Importantly, Appaduari (2008) implicates political/ financial systems: 'Can we deny that the infusion of 700 billion dollars into our banks is a magical act designed to make our banks rain credit again? Has it worked yet? Are we discarding our belief in banks and credit as a result?'.

7 See, for example, http://www.lebanonart.com/eng/ poetry14_news.htm and https://972mag.com/whenthe-canons-roar-the-israeli-left-remains-silent/92458/.

\section{Bibliography}

Agamben, G. 2008. Homo Sacer - Sovereign Power and Bare Life, trans. by Daniel Heller. Roazen Meridian: Crossing Aesthetics.

Al-Houdalieh, S. H. 2012. Archaeological Heritage and Spiritual Protection: Looting and the Jinn in Palestine. Journal of Mediterranean Archaeology, 25(1): 99-120.

al-Ju'beh, B. 2005. Magic and Talismans: The Tawfiq Canaan Collection of Palestinian Amulets. Jerusalem Quarterly, 22-23: 103.

Appaduari, A. 2008. The Magic Ballot. The Immanent Frame [online] [accessed 1 July 2016]. Available at: <http://blogs.ssrc.org/tif/2008/11/07/the-magic-ballot/>.

Arendt, H. 1978. The Life of the Mind, ed. by M. McCarthy, 2 vols. New York: Harcourt Brace Jovanovich.

Arendt, H. 1994 [1963]. Eichmann in Jerusalem: A Report on the Banality of Evil. London: Penguin Classics.

Armitstead, C. 2015. The Palestinian Poet who Inspired JK Rowling's Stance on Israel. The Guardian [online] [accessed 1 July 2016]. Available at: <https://www.theguardian.com/books/shortcuts/2015/oct/27/jk-rowlingmahmoud-darwish-israelcultural-boycott>.

Bar-el, Y., Durst, R., Katz, G., Zislin, J., Strauss, Z.\&Knobler, H. Y. 2000. Jerusalem Syndrome. British Journal of Psychiatry, 176: 86-90. 
Basu, P. \& Modest, W. eds. 2015. Museums, Heritage and International Development. London and New York: Routledge Studies.

Bowen, W. 2012. The Seven Muses of Jerusalem. San Diego Downtown News [online] [accessed 1 July 2016]. Available at: <https://sandiegodowntownnews.com/the-seven-muses-of-jerusalem/>.

Butler, B. J. 2013. Collectors, Crusaders, Carers, and Tourist Networks in Possessing Mandate Palestine. Public Archaeology, 11(4): 235-60.

Butler, B. J. 2007. Return To Alexandria - An Ethnography of Cultural Heritage Revivalism and Museum Memory. Walnut Creek, CA: Left Coast Press.

Butler, B. J. 2011. Heritage as Pharmakon and the Muses as Deconstruction: Problematising Curative Museologies and Heritage Healing. In: S. Dudley, A. J. Barnes, J. Binnie, J. Petrov and J. Walklate, eds. The Thing about Museums: Objects and Experience, Representation and Contestation. London and New York: Routledge, pp. 354-471.

Butler, B. J. \& Al-Nammari, F. 2016. 'We Palestinian Refugees' - Heritage Rites and/as the Clothing of Bare Life: Reconfiguring Paradox, Obligation and Imperative in Palestinian Refugee Camps in Jordan. Journal of Contemporary Archaeology, 3(2).

Byrne, D. 2004. Chartering Heritage in the PostmodernWorld. Conservation (The Getty Conservation Institute Newsletter), 19(2): 16-19.

Chatty, D. 2010. Dispossession and Displacement in the Modern Middle East. Cambridge: Cambridge University Press.

Cott, J. 2013. Susan Sontag: The Complete Rolling Stone Interview. New Haven and London: Yale University Press.

Coughlin, C. 1997. A Golden Basin Full of Scorpions: The Quest for Modern Jerusalem. London: Little, Brown \& Company.

Doumani, B. 2009. Archiving Palestine and the Palestinians: The Patrimony of Ihsan Nimr. The Jerusalem Quarterly, 36: 3-12.

Eliade, M. 1987. The Sacred and Profane: The Nature of Religion, trans. byW. R. Trask. New York: Harcourt.

Elon, A. 1991. Jerusalem - City of Mirrors. Glasgow: Fontana Paperbacks. 
Escobar, A. 2011. Encountering Development: The Making and Unmaking of the Third World. Princeton, NJ: Princeton University Press.

Ferguson, J. 1990. The Anti-Politics Machine: 'Development,' Depoliticization and Bureaucratic Power in Lesotho. Cambridge: Cambridge University Press.

Franke, A. ed. 2010. Animism. Berlin and New York: Sternberg Press.

Freud, S. 1984 [1936]. A Disturbance of Memory on the Acropolis. In: A Richards, ed. On Metapsychology. London: Penguin Books, pp. 443-56.

Greer, G. 1996. Slip-Shod Sibyls: Recognition, Rejection and the Woman Poet. New York: Viking.

Hirsch, M. \& Miller, N. K. 2011. Rites of Return: Diaspora Poetics and the Politics of Memory. New York: Columbia University Press.

Jacobs, D. 2009. Rough Guide to Jerusalem. London: Penguin.

Kalian, M. \& Witztum, E. 2000. Comments on Jerusalem Syndrome. British Journal of Psychiatry, 176: 492.

Latour, B. 2005. 'Thou Shall Not Freeze-Frame' or How Not to Misunderstand the Science and Religion Debate. In: J. D. Proctor, ed. Science, Religion, and the Human Experience. Oxford: Oxford Scholarship Online, pp. 27-48.

Latour, B. 2011. On the Modern Cult of the Factish Gods. Durham, NC and London: Duke University Press.

Lemonnier, P. 2012. Mundane Objects: Materiality and Non-Verbal Communication. Walnut Creek, CA: Left Coast Press.

Malkki, L. H. 1995. Refugees and Exile: From 'Refugee Studies' to the National Order of Things. Annual Review of Anthropology, 24: 495-523.

Mauss, M. 1954. The Gift: The Form and Reason for Exchange in Archaic Societies. London : Cohen and West.

Mauss, M. 1973 [1936]. Techniques of the Body. Economy and Society, 2(1): 70-88.

Mauss, M. 2006 [1943]. Techniques, Technology and Civilisation. Edited and Introduced by Nathan Schlanger. Oxford: Berghahn Books. 
Nelson, A. 2011. The Factness of Diaspora: The Social Sources of Genetic Genealogy. In: Marianne Hirsch and Nancy K. Miller, eds. Rites of Return: Diaspora Poetics and the Politics of Memory. New York: Columbia University Press, pp. 23-39.

Parish, J. 2007. Locality, Luck and Family Ornaments. Museum and Society, 5(3): 168-79.

Peteet, J. 2005. Landscape of Hope and Despair: Palestinian Refugee Camps. Philadelphia, PA: University of Pennsylvania Press.

Rolnik, E. J. 2012. Freud in Zion: Psychoanalysis and the Making of Modern Jewish. London: Karnac Books.

Rose, J. 1998. States of Fantasy. Oxford. Oxford University Press.

Rothenberg, C. 2004. Spirits of Palestine: Gender, Society, and Stories of the Jinn. Lexington Books

Shehadeh, R. 2017. 'Where the Line is Drawn': Crossing Boundaries in Occupied Palestine. London: Profile Books Ltd.

Sontag, S. 1975. Promised Lands. Documentary directed by Susan Sontag; camera, Jeri Sopanen; editing, Annie Chevalley and Florence Bocquet; produced by Nicole Stephane. New Yorker Films. Running time: 87 minutes.

Sontag, S. 2009 [1961]. Against Interpretation and Other Essays. London: Penguin Classics.

Stoller, P. 1997. Sensuous Scholarship. Philadelphia, PA: University of Pennsylvania Press.

Sugarman, S. 1998. Freud on the Acropolis: Reflections on a Paradoxical Response to the Real. Boulder, CO: Westview Press.

Tamari, S. 2009. Lepers, Lunatics and Saints: The Nativist Ethnography of Tawfiq Canaan and his Jerusalem Circle. In: S. Tamari, ed. Mountain Against the Sea: Essays on Palestinian Society and Culture. Berkeley: University of California Press, pp. 93-112 .

Taylor, D. 2011. Trauma as Durational Performance: A Return to Dark Sites. In: Marianne Hirsch and Nancy K.

Miller, eds. Rites of Return: Diaspora Poetics and the Politics of Memory. New York: Columbia University Press, pp. 268-79.

Van der Haven, A. 2008. The Holy Fool Still Speaks. The Jerusalem Syndrome as a Religious Subculture. In: T. Mayer and S. A. Mourad, eds. Jerusalem. Idea and Reality. London: Routledge, pp. 103-22.

Warnier, J-P. 2007. The Pot King: The Body and Technologies of Power. Leiden: Brill. 
Warnier, J-P. 2009. Technology as Efficacious Action on Objects and Subjects. Journal of Material Culture, 14(4): 459-70.

Weiner, A. B. 1983. From Words to Objects to Magic: Hard Words and the Boundaries of Social Action. Man 18(4): 690-709.

Weizman, E. 2007. Hollow Land: Israel's Architecture of Occupation. New York: Verso Books.

\section{Notes on contributor}

Dr Beverley Butler is a Reader in Cultural Heritage at UCL Institute of Archaeology.

Her key interests include: Critical Heritage perspectives, 'Heritage Wellbeing' and the transformative 'efficacies of heritage' particularly in contexts of marginalisation, displacement, conflict and extremis. Beverley has ongoing long-term fieldwork research in the Middle East - notably, in Egypt, Palestine and Jordan. Her longstanding research collaboration with Dr Fatima Al-Nammari (Petra University Jordan) includes: Dislocated Identities and 'Non-places' - Heritage, Placemaking and Wellbeing in Refugee Camps (2011- ongoing). Beverley is Co-Investigator on a new joint ESRC/AHRC Global Challenges Research Fund research project with Professor Helen Chatterjee in collaboration with the Helen Bamber Centre which looks at the role of creative arts and cultural activities in improving health and well-being. Correspondence to: Dr Beverley Butler, UCL Institute of Archaeology, 31-34 Gordon Square, London WC1H OPY, UK. Email: beverley.butler@ucl.ac.uk 